Contents list available at IJRED website

Int. Journal of Renewable Energy Development (IJRED)

Journal homepage: www.ijred.com

\title{
Enhancing Ethanol Production by Fermentation Using Saccharomyces cereviseae under Vacuum Condition in Batch Operation
}

\author{
Abdullah* and Dessy Ariyanti \\ Chemical Engineering Department, Faculty of Engineering, Diponegoro University, \\ Jl.Prof Sudharto,SH-Tembalang, Semarang INDONESIA
}

\section{Article history:}

Received December 26, 2011 Received in revised form Jan 15, 2012 Accepted January 23, 2012 Available online

\begin{abstract}
Ethanol is one of renewable energy, which considered being an excellent alternative clean-burning fuel to replaced gasoline. In fact, the application of ethanol as fuel still blended with gasoline. The advantages of using ethanol as fuel are that the raw material mostly from renewable resources and the product has low emission which means environmental friendly. Ethanol can be produced by fermentation of sugars (glucose/fructose). The constraint in the ethanol fermentation batch or continuous process is the ethanol product inhibition. Inhibition in ethanol productivity and cell growth can be overcome by taking the product continuously from the fermentor. The process can be done by using a vacuum fermentation. The objective of this research is to investigate the effect of pressure and glucose concentration in ethanol fermentation. The research was conducted in laboratory scale and batch process. Equipment consists of fermentor with vacuum system. The observed responses were dried cells of yeast, concentration of glucose, and concentration of ethanol. Observations were made every 4 hours during a day of experiment. The results show that the formation of ethanol has a growth-associated product characteristic under vacuum operation. Vacuum condition can increase the cell formation productivity and the ethanol formation, as it is compared with fermentation under atmospheric condition. The maximum cells productivity and ethanol formation in batch operation under vacuum condition was reached at $166.6 \mathrm{mmHg}$ of pressure. The maximum numbers of cells and ethanol formation was reached at $141.2 \mathrm{~mm} \mathrm{Hg}$ of pressure. High initial glucose concentration significantly can affect the productivity and the yield of ethanol.
\end{abstract}

Keywords: Ethanol fermentation, Ethanol productivity, Concentration of glucose, Vacuum pressure

\section{Introduction}

Currently the final energy supply is dominated by non-renewable energy resources such as oil, gas and coal which totally achieved $95.8 \%$ of the final energy consumption of 97 MTOE. This situation worrying the government and the energy society as the fossil energy resources and supply will be diminished in the near future [1]. Fossil fuel such as crude oil, were refines to produce derivatives products like solar and gasoline to full fill the transportation needed. The alternative energy which produced from renewable resources to address transportation fuels are biodiesel and bioethanol as substitute for solar fuel and petrol / gasoline.
Ethanol is one of renewable energy, which considered being an excellent alternative clean-burning fuel to replaced gasoline. In fact, the application of ethanol as fuel still blended with gasoline. The advantages of using ethanol as fuel are that the raw material mostly from renewable resources and the product has low emission which means environmental friendly [2]. Ethanol can be produced by several processes such as ethylene hydration process and fermentation process. Ethanol can be produced by fermentation using mono / disaccharide (sugar cane, molasses) as raw material, starchy ingredients (corn, rice or other crops) and cellulosic materials (wood, agricultural waste). Ethylene hydration process is commonly used if large oil reserves available; while

\footnotetext{
* Corresponding author. Tel: +62-24-7460058

E-mail: $\underline{\text { abd_busairi@yahoo.com }}$
} 
fermentation process is choose in country which did not have large number of fossil oil reserve.

Fermentation technology has a bright prospect as a method for producing ethanol. This is because of the raw material is cheap and moreover it is renewable. Ethanol fermentation process can be carried in bulk / batch or continuous or continuous.

The main obstacle in the process of operation of bulk fermentation process is it time consuming. Meanwhile, continuous process operations have a short processing time and high productivity. However, the same constraint in both process operations is product inhibition by ethanol [3]. Inhibition in ethanol productivity and cell growth can be overcome by taking the product continuously from the fermentor. The separation of ethanol during the fermentation process should be done without disturbing the life of yeast. In order to full fill the above requirement, fermentation can be done in vacuum condition.

Ethanol is widely used as solvents, germicides, drinks, anti-freeze, fuel, and the synthetic compounds and other organic compounds. Ethanol as a solvent widely used in the pharmaceutical industry, cosmetics, and resin as well as laboratories. In Indonesia, the beverage industry is the largest user of ethanol, followed successively by acetic acid industry, the pharmaceutical industry, cosmetics, hospitals and other industries. As feedstock, ethanol is used for the preparation of a compound acetaldehyde, butadiene, diethyl ether, ethyl acetate, acetic acid, and so forth. Ethanol, which is known as absolute alcohol is one of the alternative energy sources. Ethanol can be used as a blending ingredient in gasoline is better known as "gasohol" [4].

Ethanol fermentation is a process of anaerobic metabolism. Overall reaction occurs in anaerobic conditions, following the equation following GayLussac:

$$
\mathrm{C}_{6} \mathrm{H}_{12} \mathrm{O}_{6} \rightarrow 2 \mathrm{C}_{2} \mathrm{H}_{5} \mathrm{OH}+2 \mathrm{CO}_{2}+\text { energy }
$$

One gram of glucose will produce 0.51 grams of ethanol with several by-products such as: acetaldehyde (ether fraction) and fusel oil, which a mixture of volatile, oily liquids produced in small amounts [5].

This research generally aims to develop the process of ethanol production by yeast fermentation process Sacharomyces cereviseae using molasses as raw material. The effect of variation operating pressure and the initial of glucose concentration to ethanol fermentation process were investigated.

\section{Experimental Method}

Research was conducted in Laboratory of Microbiology and Bioprocess, Chemical Engineering Department, Faculty of Engineering, University of Diponegoro Semarang. Materials used are several chemicals such as phenolphthalein indicator, potassium phosphate, ammonium nitrate, hydrochloric acid, sucrose, fructose, and glucose. Saccharomyces cereviseae strains were obtained from the Laboratory of Microbiology Faculty of Mathematics and Natural Sciences Department of Biology UNDIP Semarang.

The main equipment used consists of two tools for the fermentation process/fermenters and vacuum pump unit as figure 1 . The circuit comprises a tool consisting of stirred bioreactor (Bio G-MICOM System) with a cooling reactor, temperature and $\mathrm{pH}$ indicator. Bioreactor was from BIOTRON, Inc. Volume of $2000 \mathrm{ml}$ of fermentation media.

Fermentation medium used is glucose of $100 \mathrm{~g} / \mathrm{L}$. Fermentation medium supplemented with potassium phosphate $3 \mathrm{~g} / \mathrm{L}$, ammonium chloride $2.5 \mathrm{~g} / \mathrm{L}$, calcium chloride $0.01 \mathrm{~g} / \mathrm{L}$, sodium hydrogen phosphate $5.5 \mathrm{~g} /$ $\mathrm{L}$, yeast concentration of $7 \mathrm{~g} / \mathrm{L}$ and $\mathrm{MgSO}_{4} 0,25 \mathrm{~g} / \mathrm{L}$. Media were sterilized by heating in boiling bath and maintained at a temperature of $125^{\circ} \mathrm{C}$, for 1 hour, then cooled at room temperature. $\mathrm{PH}$ conditions are set according to the variety and added nutrients. Yeast was added into the media and fermentation done for a day. Analysis was done every 4 hours, the parameter observed such as ethanol concentration and sugar content.

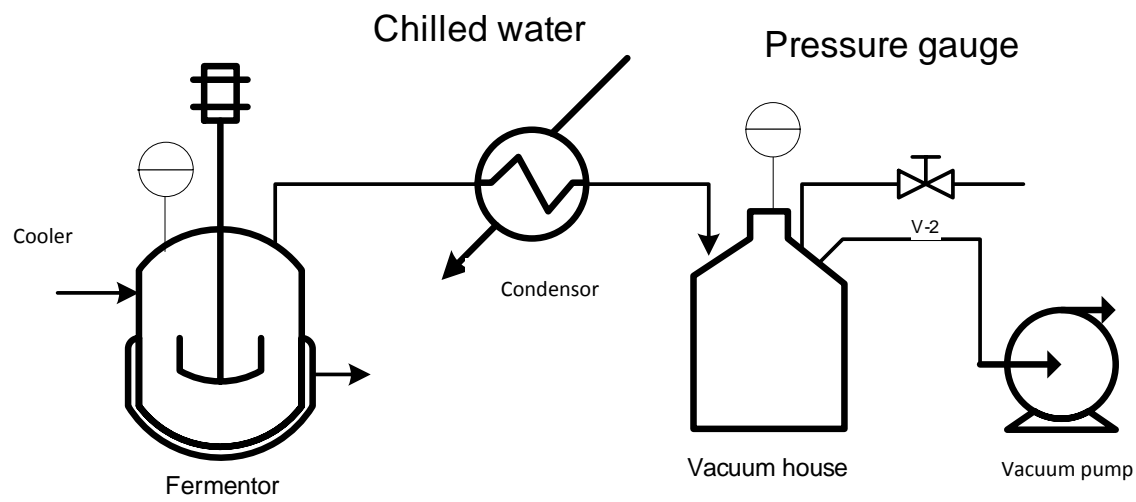

Fig. 1 Bioreactor with the fermentation process vacuum system 


\section{Results and Discussion}

In ethanol fermentation, glucose is serving as subtract for yeast and ethanol production by yeast metabolisms. Cell growth during ethanol fermentation is undesirable events. Still grown yeast during ethanol fermentation takes place. The research conducted also showed a similar trend. This is like presented in Fig 2.

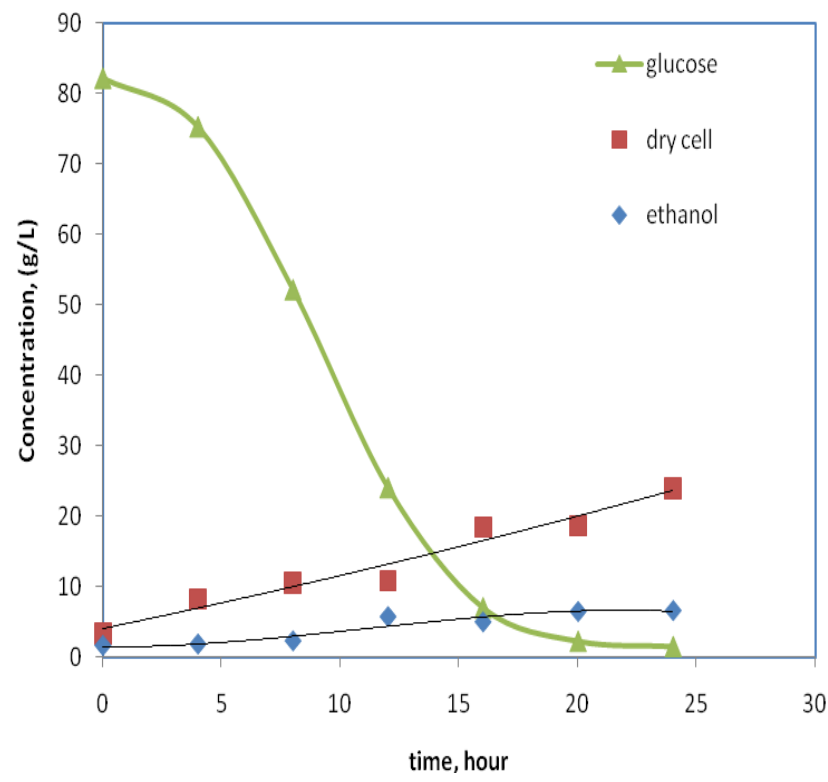

Fig. 2 Concentration versus time in $166.6 \mathrm{mmHg}$

Productivity of cells in fermentation under vacuum condition is higher than fermentation under atmospheric condition. This is due to the ethanol formed directly vaporized in vacuum condition. Ethanol inhibition of cell growth can be observed at a concentration of ethanol $15 \mathrm{~g} / \mathrm{L}$. The cell will stop growing when the concentration of ethanol in the medium reached $105 \mathrm{~g} / \mathrm{L}$ [3]. The highest cell productivity was obtained at the operating pressure of $166.6 \mathrm{mmHg}$ with value $0.870 \mathrm{~g} / \mathrm{L}$ hour.

The formation of ethanol is linier with the concentration of yeast cells (growth-associated product). This observation also indicated the same under vacuum condition (Fig 2). The trend observed in all experiment shows that the increment of product was followed by the increment of cell concentration. It can be stated, that cell growth and product formation in batch operation under vacuum condition were have a similar tendency to the fermentation at atmospheric pressure, which means ethanol fermentation has a growth-associated product characteristic. Pressure value were not interfere the growth of the cell and formation of ethanol. Highest ethanol productivity in this experiment is achieved at a pressure of 166.6 $\mathrm{mmHg}$ with value $2.11 \mathrm{~g} / \mathrm{L}$. hour.

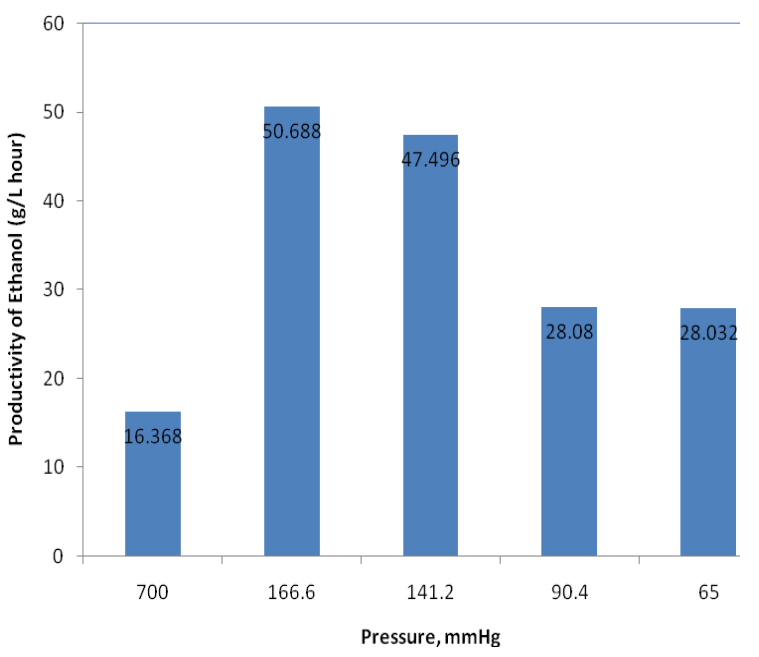

Fig. 3. Ethanol production in various pressure condition

Figure 3 shows the ethanol production in various pressure conditions. Ethanol productivity in all operating vacuum were higher than atmospheric pressure batch operation. These phenomena can be explains that during vacuum operation the ethanol produced were directly vaporized and recovered from the fermentation media, by means inhibition of product formation can be reduced [6]. Highest ethanol production was obtained at $166.6 \mathrm{~mm} \mathrm{Hg}$ vacuum.

The meaning of productivity is the rate of product formation in substrate-product-solvent mixture system. This parameter was significantly important in the discussion of continuous fermentation systems. Meanwhile, the common parameters considered in the batch system is the yield of raw material conversion (in this case glucose) into a product (in this case the cells and ethanol). Cell recovered and ethanol formation in vacuum batch fermentation process shown in Figure 4 and Figure 5.

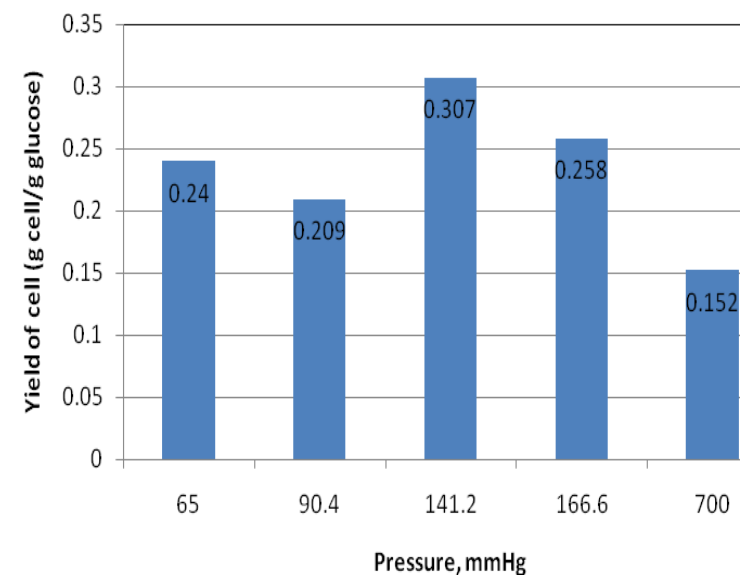

Fig. 4. Cell generated in various pressure condition 


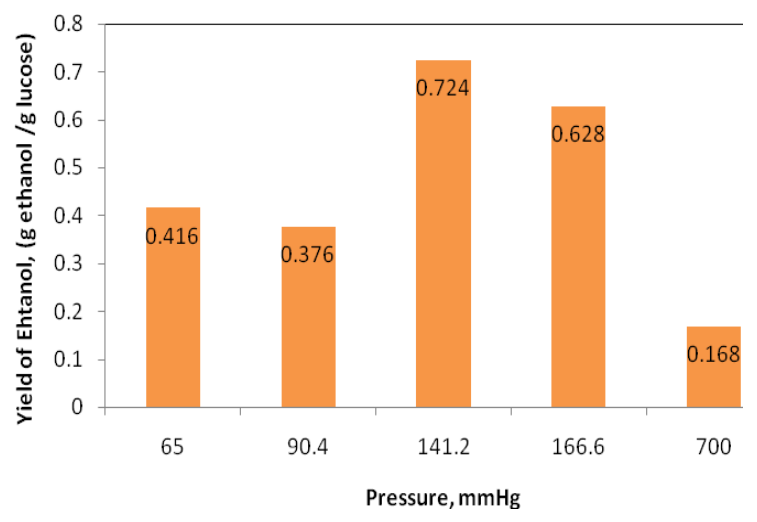

Fig. 5. Yield of ethanol in various pressure condition

Figure 4 and 5 proves that this type of formation is the growth associated ethanol product characteristic. The figure also shows that process under vacuum conditions can increase the yield of cells and ethanol formation, with maximum value was achieved at a pressure of $141.2 \mathrm{mmHg}$. The maximum value of yield of cells and ethanol formation were is $0.310 \mathrm{~g}$ cell $/ \mathrm{g}$ glucose and $0.724 \mathrm{~g}$ ethanol/g glucose respectively.

Batch fermentation experiments under vacuum condition (65 mmHg) with initial glucose concentration $34.4 \mathrm{~g} / \mathrm{L}$ and $174.6 \mathrm{~g} / \mathrm{L}$ were performed to determine the effect of elevated levels of glucose in the productivity of cells and ethanol yield. Figure 5 shows the results of the experiments in variation of glucose concentration

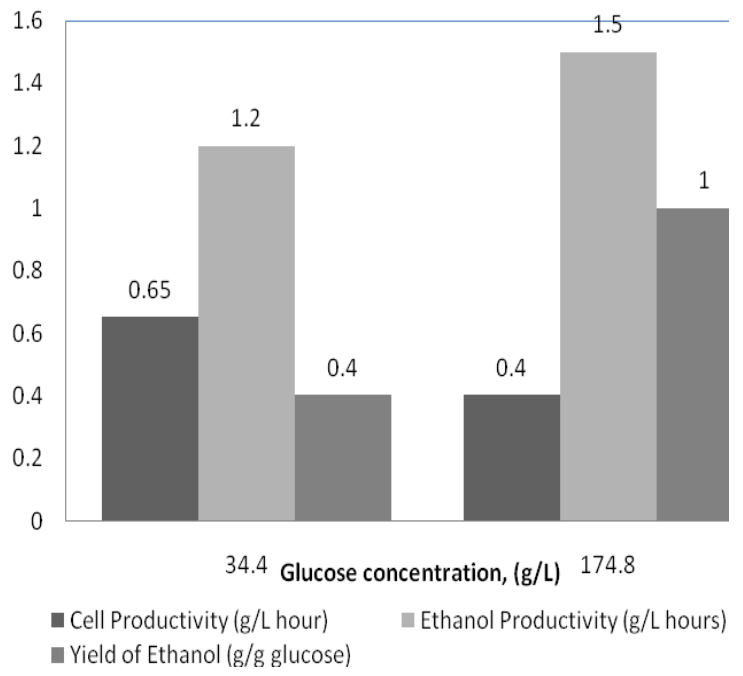

Fig. 6. The effect of glucose concentration in productivity and yield at pressure condition $65 \mathrm{mmHg}$
The increment of glucose concentration from 34.4 to $174.6 \mathrm{~g} / \mathrm{L}$ increases the ethanol productivity and yield. In reverse, the productivity and the recovery of cell decrease. Ethanol productivity increased 1.3 times while the yield of ethanol increased 2.42 times. This phenomenon like presented in Fig 6.

At the metabolic chain point of view, the above condition is related to the enzymatic process of pyruvic acid which is intermediate product of glycolysis process (glucose degradation). Growth of cells will occurs when the pyruvate inserted into tri carboxylic acid chains supported by enzyme pyruvate dehydrogenase complex. The formation of ethanol from pyruvate occurs if pyruvate is converted into acetaldehyde by pyruvate decarboxylase enzyme aid, then with by the force from alcohol dehydrogenase enzyme, acetaldehyde then converted into ethanol.

\section{Conclusion}

Ethanol formation has growth-associated product characteristic if the ethanol fermentation process carried out in vacuum condition. Vacuum condition can increase the cell formation productivity and the ethanol formation, as it is compared with fermentation under atmospheric condition. The maximum cells productivity and ethanol formation in batch operation under vacuum condition was reached at $166.6 \mathrm{mmHg}$ of pressure. The maximum numbers of cells and ethanol formation was reached at $141.2 \mathrm{~mm} \mathrm{Hg}$ of pressure. High initial glucose concentration significantly can affect the productivity and the yield of ethanol.

\section{References}

[1] Ibrahim HD, Thaib NM, Wahid LMA (2010) Indonesian Energy Scenario to 2050: Projection of Consumption, Supply Options and Primary Energy Mix Scenarios.

[2] Bailey BK (1996) Performance of Etanol as a Transportation Fuel dalam Hand Book on Bioetanol: Production and Utilization, editor C.E., Wayman, Taylor \& Francis, Washington. pp: 37-60.

[3] Luong JHT (1984) Kinetics of Etanol Inhibition in Alcohol Fermentaton, Biotechnology and Bioengineering, Vol. XXVI John \& Wiley Sons, Inc. pp: 280-285.

[4] Keller JL, Mai (1979) Alcohols Motor Fuel?. Hydrocarbon Processing: $127-138$.

[5] Maiorella BL (1985) Etanol dalam Comphrehensive Biotechnology : The Principles, Application and Regulation of Biotechnology in Industry, Agriculture and Medicine, editor M. Moo-Young, Vol. 3, Pergamon Press Ltd., pp: 861-914.

[6] Kosaric N, Wieczorek A, Cosentino GP, Magee, RJ Prenosil JE (1983) Etanol Fermentation, editor H.J., Rehm dan G., Reed., Biotechnology, Vol. 3., Verlag-Chemie, Weinheim, Jerman. Pp: 257-385. 